Riga, Latvia, November 15, 2019

\title{
ARCHITECTURE
}

\section{ARCHETYPAL PROTOTYPES OF VARIOUS ARTFICIAL LIGHTING SYSTEMS}

\section{Lidiya Koval ${ }^{1}$ \\ Angelina Tregub ${ }^{2}$}

DOI: https://doi.org/10.30525/978-9934-588-13-6-1

Broadly defined, archetypes are cross-cutting, symbolic structures of cultural history that associate certain topical material of conscious and subconscious functioning of human values [8, p. 39], and, getting into immediate human environment in the form of symbols, evoke deep sensations [6, p. 17]. To some extent, symbol is a manifestation of archetype in the material world [2], from the symbolic point of view archetypes are propensities to the implementation of certain images or ideas, as well as their prototypes or opportunities to their embodiment in the cultural processes [8, p. 39].

A separate category of archetypes is formed by cosmological phenomena the sun, stars, rainbow, etc. The most common is the archetype of the sun that can also manifest itself through a closely related symbolic image of fire [3, p. 152] or as impinging sunlight; the second most popular archetype is the sky which is present almost in very religion [4, p. 133]. In the majority of cultures, the sun is a symbol of creative energy [5, p. 401-404], and fire is perceived as demiurge that emerges from the sun (being its earthly emanation) and correlates with sunbeam and lighting. Anthropologists trace the cult of fire in many modern festivals (fireworks, Christmas tree lights) [5, p. 296-298].

An additional group is made by national archetypes [8, p. 39], that embody the historic experience of the communities, influence the inner world of separate personalities, shape primary relationships and regulate them in the society. In the Ukrainian culture some archetypes, having lofty semantic charge and being some of the basic ones during the Pre-Christian period, enjoy the same status at present [2]. They embrace the archetype of light, and images of light and fire are identified as conforming to life, sense, and wisdom [7]. In Arabian sources, the word 'fire-worshippers' was used in relation to the Slavs who considered home fire, as well as the sun, sacred. Such worldview, present in the Slavic unconscious as early as in the pagan

\footnotetext{
${ }^{1}$ Kyiv National University of Construction and Architecture, Ukraine

${ }^{2}$ Classic Private University, Ukraine
} 
period, was transferred to the Christian phenomena. That is why this enables us to state fire as an archetype for the Ukrainian unconscious [2].

According to the mentioned above, we can acknowledge tight interrelation of archetypes of the sun and fire, as well as human's subconscious perception of fire as of earthly emanation of the sun (especially in the Ukrainian culture). This is also confirmed by the history of artificial illumination development $[1$, p. 6-43], in accordance with which for more than million years human consciousness and unconscious were formed under the influence of two sources of light: the sun as a source of daylight that determined the period of active work and vigor (concentration on complicated visual tasks), and flame as a source of light in the evening and at night, which in the initial stages of human evolution became a sort of portable sun for primal communities, creating conditions for communication between the members of that primary human group, evoking the sense of security, comfort and trust between the members of that group, and facilitating transfer of that practice to new generations.

Therefore, daylight can be considered a prototype of any system of functional work lighting, and the light from fire - a prototype of those systems of illumination that are designed for relaxation and communication.

\section{References:}

1. Charlotte \& Peter Fiell. (2013). 1000 Lights. Köln: TASCHEN GmbH.

2. Karas, I. (2017). Arkhetyp vognyu v ukrainskii kulturi [The archetype of fire in Ukrainian culture]. Proceedings of the Tendentsii I perspektyvy rozvytku istorychnoyi nauky ta filosofiyi v umovakh globalizatsii (Kyiv, 2017). Kyiv, pp. 241-251.

3. Khavkina, L. (2010). Suchasnyi ukrainskyi reklamnyi mif [Modern Ukrainian advertising myth]. Kharkiv: Kharkivske istoryko-filologichne tovarystvo. (in Ukrainian)

4. Kubko, V. P. (2009). Kreatyvni tekhnologii v reklami [Creative technologies in advertising]. Odesa: ONPU. (in Ukrainian)

5. Kyrlo Kh. (2010). Slovar simvolov. 1000 statey o vazhneishykh ponyztiyakh religii, literatury, arkhitektury, istorii [Dictionary of characters. 1000 articles on the most important concepts of religion, literature, architecture, history]. Moscow: ZAO Tsentrpoligraf. (in Russian)

6. Mark, M., \& Pearson, K. (2005). Geroi $i$ buntar. Sozdaniye Brenda s pomoshchyu arkhetipov [Hero and rebel. Creating a brand using archetypes]. Saint Petersburg: Pier. (in Russian)

7. Mischenko M. M. Ukrainski natsionalny arkhetypy: vid kolektyvnogo nesvidomogo do usvidomlenoyi natsionalnoyi identychnosti (do aktualnosti metodologiyi arkhetypichnogo analizu) [Ukrainian national archetypes: from the collective unconscious to the conscious national identity]. Retrieved from: http://www.kpi.kharkov.ua/archive/articles/etic/Mishhenko-M.M.-Ukrayinski-natsionalniarhetypy.pdf (accessed 14 November 2019).

8. Ozadovska L. V., Polishchuk N. P. (ed.) (2002). Filosofskyi entsyklopedychnyi slovnyk [Encyclopedic Dictionary of Philosophy]. Kyiv: Abrys. (in Ukrainian) 